\title{
Water Quality Monitoring in Kpassa Reservoir (Northen Benin): Physico-Chemical Parameters, Trophic State and N: P Ratio
}

\author{
Ousmane Touré Boukari ${ }^{1,}$, , Moctar Limam Bawa ${ }^{2}$, Daouda Mama $^{1}$, Youssouf Abou ${ }^{3}$ \\ ${ }^{1}$ Department of Hydrology and Integrated Management of Water Resources, University of Abomey-Calavi, Abomey-Calavi, Benin \\ ${ }^{2}$ Department of Chemistry, University of Lomé, Lomé, Togo \\ ${ }^{3}$ Department of Zoology, University of Abomey-Calavi, Abomey-Calavi, Benin
}

\section{Email address:}

oboukari3@gmail.com (O. T. Boukari), bawamoktar@yahoo.fr (M. L. Bawa), mkdaouda@yahoo.fr (D. Mama), y_abou@yahoo.com (Y. Abou)

${ }^{*}$ Corresponding author

\section{To cite this article:}

Ousmane Touré Boukari, Moctar Limam Bawa, Daouda Mama, Youssouf Abou. Water Quality Monitoring in Kpassa Reservoir (Northen Benin): Physico-Chemical Parameters, Trophic State and N: P Ratio. Journal of Water Resources and Ocean Science.

Vol. 7, No. 1, 2018, pp. 1-9. doi: 10.11648/j.wros.20180701.11

Received: November 17, 2017; Accepted: December 5, 2017; Published: January 12, 2018

\begin{abstract}
The study was carried out to assess the physico-chemical parameters, the trophic state and the N:P ratio of the Kpassa reservoir. The reservoir was studied at six sampling sites over the period going from August 2014 to May 2016. Water transparency was determined in situ with the secchi disk SDMO QUINIOU model F043SE. Chlorophyll a, $\mathrm{NO}_{3}{ }^{-}, \mathrm{NO}_{2}{ }^{-}, \mathrm{NH}_{4}{ }^{+}$, $\mathrm{PO}_{4}{ }^{3-}$ and total phosphorus were analyzed using the standard methods. Measures were made with the HACH DR2800 spectrophotometer. The trophic state was assessed using the Carlson's trophic state index (TSI). The N:P ratio was evaluated using $\mathrm{NO}_{3}{ }^{-}, \mathrm{NO}_{2}{ }^{-}, \mathrm{NH}_{4}{ }^{+}$and $\mathrm{PO}_{4}{ }^{3-}$ concentrations. The physico-chemical parameters investigated were: transparency $(0.25$ $1.92 \mathrm{~m}$ ), chlorophyll a $(8.2-233.46 \mu \mathrm{g} / \mathrm{L}$ ), nitrate (undetected- $4.73 \mathrm{mg} / \mathrm{L}$ ), nitrite (undetected- $0.23 \mathrm{mg} / \mathrm{L}$ ), ammonia (undetected$0.21 \mathrm{mg} / \mathrm{L})$, orthophosphate $(0.03-1.04 \mathrm{mg} / \mathrm{L})$ and total phosphorus $(0.1-3.2 \mathrm{mg} / \mathrm{L})$. The trophic state index (TSI) values oscillate between 38 and 59. The majority of the values are characteristic of mesotrophic conditions. Kpassa reservoir is eutrophic only in August 2014 at the whole studied stations. N:P ratio values vary between 0.22 and 60.46 showing that eutrophication in Kpassa reservoir is limited by phosphorus and nitrogen. Some physico-chemical parameters values are upper than the WHO and Ifremer safe limit making the reservoir water unfit for human consumption at the concerned sites and during the concerned period. It is recommended that the national company of Benin water (SONEB) sensitize the population on the rational use of the fertilizers and the adoption of water control technics in the farm. Washing and crockery activities should be also forbidden along the reservoir river. The trophic state of the reservoir seems improved compared to previous studies results. According to the N: P ratio values, measurements to be implemented for eutrophication management in Kpassa reservoir should emphasize on the control of the flow of nitrogen and phosphorus compounds.
\end{abstract}

Keywords: Water Quality, Physico-Chemical Parameters, Trophic State, N: P Ratio, Kpassa Reservoir, Okpara, Parakou, Benin

\section{Introduction}

The massive loading of nutrients and organic matter into surface water disturbs the natural balances of the aquatic ecosystems. The most visible consequence of this type of pollution is the eutrophication of rivers [1]. Nowadays, lagoon and sea ecosystems which have a great ecological interest as well as economic are more and more marked by accentuated degrees of eutrophication [2]. Eutrophication is the enrichment of the water with nutrients, especially nitrogen and phosphorus compounds, which cause accelerated growth of algae and higher forms of plant life, as a result of which undesired disturbances of water ecosystems 
and the deterioration of water quality take place [3]. According to Zalewski [4], freshwater rivers are essential sources of water and it is necessary to study, protect, and improve their ecological status. Ensuring that water quality in aquatic environments remains within natural ranges is essential for sustaining viable, abundant, and diverse communities of organisms. Degradation of water quality erodes the availability of water for humans and ecosystem and decreases species diversity and abundance of resident communities [5]. In this respect, researches in water quality are important to increase the awareness of more efficient use of water and water resources that are the most precious treasure of humankind [6]. Several indexes have been developed to assess eutrophication and water quality in aquatic ecosystems based on chemical, physical and biological parameters [7]. Carlson's trophic state index (TSI) is the most widely used in freshwater bodies [8].

In the field of the water management, the identification of an limiting nutrient is essential for the planning of effective measures against eutrophication [9]. N:P ratio represents one of the tools frequently used to identify the factor limiting the eutrophication of lakes and rivers. The primary production in the aquatic ecosystems is commonly limited by phosphorus or nitrogen or both [10].

However, Kpassa reservoir, the main source of drinking water of Parakou city in north-east of Benin, suffering from eutrophication since 2000. This situation arouses the interest of aquatic environment managers and researchers. The physico-chemical properties and the trophic state of the reservoir have been investigated by [11]. Same work was made by [12]. [13] provided recent data on the physicochemical characteristics of the reservoir including its trophic state and N:P ratio. The present study aimed at carrying out similar work over the period going from august 2014 to may 2016.

\section{Material and Methods}

\subsection{Area Investigated}

Located at $13.5 \mathrm{~km}$ at east of Parakou city (N 09¹7'034; E $002^{\circ} 43^{\prime} 975$ ) in Borgou department, Kpassa reservoir on Okpara with an area of 190 ha [14] (Figure 1) has mainly the role to supply the 254254 inhabitants [15] of Parakou in drinking water. Parakou city is located at $\mathrm{N} 09^{\circ} 21^{\prime}$ and E $02^{\circ} 36^{\prime}$ in north-east of Benin, at $450 \mathrm{~km}$ from the economic capital Cotonou and at an average altitude of $350 \mathrm{~m}$ [11]. Okpara is one of the tributaries of river Ouémé in Benin [16]. The National Company of Benin Water (SONEB) started to supply Parakou city in drinking water since 1975 with raw water pumped from Kpassa reservoir. The dyke of the reservoir is built in laterite over a length of $480 \mathrm{~m}$ and a height of $10 \mathrm{~m}$. Two overfall located on the Southern part of the reservoir are used to control the water level. The pumping station, equipped with two pumps of $350 \mathrm{~m}^{3} / \mathrm{h}$ each one, is installed on the reservoir at $105 \mathrm{~m}$ from the Western shoreline. A first treatment of the raw water is made insitu before aspired towards the treatment plant located at Banikani district in Parakou. The volume of water available in Kpassa reservoir is estimated at 8.2 million $\mathrm{m}^{3}$, either original volume of 9.4 million $\mathrm{m}^{3}$ obtained in 1972 decreased by 1.2 million $\mathrm{m}^{3}$ of sediment estimated in 2014 [17]. The reservoir is deep and shallow at some locations with depth varies between 1.5 and $8.5 \mathrm{~m}$. It is cover on about $90 \%$ of its surface by aquatic plants [18].

The basin of Kpassa reservoir covers the district of Bembèrèkè, Nikki, N'Dali, Pèrèrè, Parakou and Tchaourou [19]. The portion of Okpara river delimited by the basin and its tributaries, Niessi, Nioré and Sabi with a length respectively of $41.5 \mathrm{~km}, 32 \mathrm{~km}$ and $18 \mathrm{~km}$ supply water to Kpassa reservoir [20]. The basin is under the influence of the Soudanian wet tropical climate. The wet season go from May to October and the dry season from November to April. The area is also under the influence of the wind called harmattan. The low temperatures recorded during the dry season are related to the occurrence of this wind. Agriculture is the main activity of the study area. Breeding and fishing are also much practiced. Breeding is developed and varied with bovine, sheep, caprine, porcine and poultry.

\subsection{Sampling Design}

The water samples were collected from six sampling sites between August 2014 and May 2016 (Table 1). The stations were selected based on their accessibility and the potential pollution sources localization (Figure 1). At each sampling station, 1.5 liter of water were collected in polyethylene bottle at a depth of $30 \mathrm{~cm}$ for the measurement of physical and chemical parameters. All samples were stored in ice containers during their transport to the laboratory.

Table 1. Description of the sampling months and corresponding seasons.

\begin{tabular}{lllllllllll}
\hline Months & Aug14 & Oct 14 & Dec 14 & Febr15 & April15 & Sept15 & Nov 15 & Jan 16 & March16 & May 16 \\
\hline Seasons & rainy & rainy & dry & dry & dry & rainy & dry & dry & dry & rainy \\
\hline
\end{tabular}

Aug 14 = August 2014; Oct $14=$ October 2014; Dec 14 = December 2014; Febr $15=$ February 2015;

April 15 = April 2015; Sept $15=$ September 2015; Nov $15=$ November 2015; Jan $16=$ January 2016;

March 16 = March 2016; May $16=$ May 2016.

\subsection{Physico-Chemical Analysis of Water}

The physico-chemical parameters which describe the trophic state and the N:P ratio were analyzed. Water transparency (SD) was measured in the field by secchi disk
SDMO QUINIOU model F043SE. The concentrations of nitrate $(\lambda=400 \mathrm{~nm})$, nitrite $(\lambda=507 \mathrm{~nm})$, ammonia $(\lambda=655 \mathrm{~nm})$, orthophosphate $(\lambda=880 \mathrm{~nm})$ and total phosphorous $(\lambda=880 \mathrm{~nm})$ in water samples were determined according to the standard methods described by [21]. Analysis of 
chlorophyll a was performed according to [22]. Measures were made with the HACH DR2800 spectrophotometer.

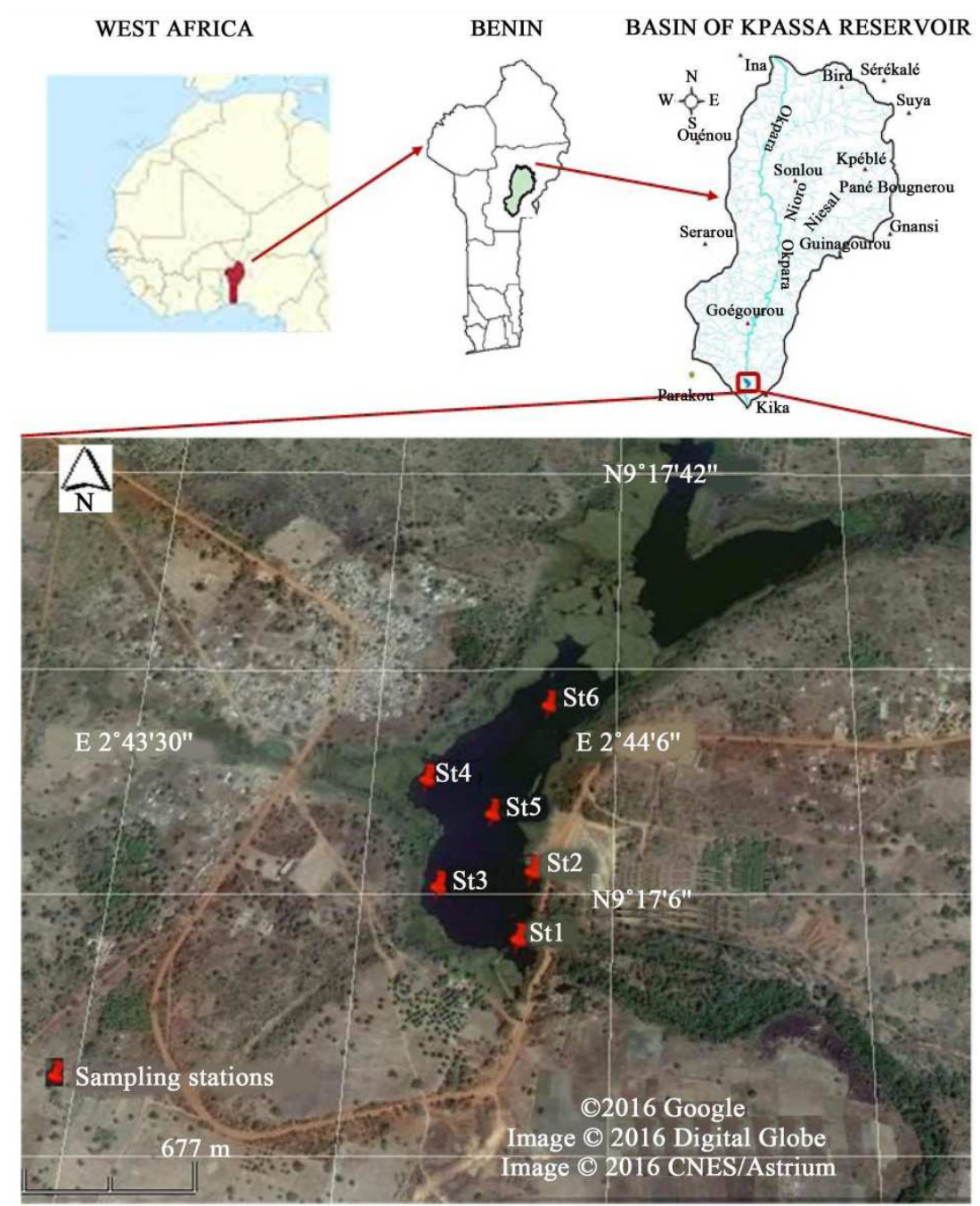

Figure 1. Localization of Kpassa reservoir showing the sampling sites [13].

\subsection{Data Analysis}

\subsubsection{Trophic State Evaluation}

The trophic state of the reservoir was determined by the classical freshwater Trophic State Index (TSI) of [8]. TSI was calculated with chlorophyll a $(\mathrm{Chl}$ a) $(\mu \mathrm{g} / \mathrm{L})$, Secchi depth (SD) (m) and total phosphorus (TP), using to the following equations:

$$
\begin{gathered}
\text { TSI }(\mathrm{Chl} \text { a })=9.81 \ln (\mathrm{Chl} \text { a })+30.6 \\
\text { TSI }(\mathrm{SD})=60-14.41 \ln (\mathrm{SD}) \\
\text { TSI }(\mathrm{TP})=14.42 \ln (\mathrm{TP})+4.15
\end{gathered}
$$

The overall TSI was calculated as the average value of TSI (Chl a), TSI (SD) and TSI (TP) as follows:

$$
\mathrm{TSI}=\frac{\mathrm{TSI}(\mathrm{Chl} \mathrm{a})+\mathrm{TSI}(\mathrm{SD})+\mathrm{TSI}(\mathrm{TP})}{3}
$$

The Carlson's scale indicating the trophic state is a whole indexes varying from 0 to 100 (Table 2).
Table 2. Limit values of TSI indicating the trophic state.

\begin{tabular}{ll}
\hline Trophic state & TSI values \\
\hline Oligotrophic & $0-40$ \\
Mesotrophic & $40-50$ \\
Eutrophic & $50-70$ \\
hypereutrophic & $70-100$ \\
\hline
\end{tabular}

\subsubsection{N:P Ratio Evaluation}

$\mathrm{N}$ and $\mathrm{P}$ concentrations was calculated using $\mathrm{NO}_{3}{ }^{-}, \mathrm{NO}_{2}{ }^{-}$, $\mathrm{NH}_{4}{ }^{+}$and $\mathrm{PO}_{4}{ }^{3-}$ concentrations as follow:

$$
\begin{gathered}
\mathrm{N}=\mathrm{NO}_{3}{ }^{-}+\mathrm{NO}_{2}{ }^{-}+\mathrm{NH}_{4}{ }^{+} \\
\mathrm{P}=\mathrm{PO}_{4}{ }^{3-}
\end{gathered}
$$

The obtained N:P ratio were compared with the standard [23] ratio $(\mathrm{N}: \mathrm{P}=16: 1)$. Nitrogen or phosphorus is the limiting factor respectively if $\mathrm{N}: \mathrm{P}$ ratio value is lower or upper than 16:1.

Graphics were generated using SPSS (Statistical Package for the Social Sciences) software version 16.0. 


\section{Results and Discussion}

\subsection{Physico-Chemical Parameters}

\subsubsection{Transparency and Chlorophyll a Variation}

Transparency is how easily light can pass through a substance. In other words, when the water is murky or cloudy and contains a lot of particles, the light cannot penetrate as deeply into the water column which hence limits primary productivity [24]. In surface water, transparency varies according to the phytoplankton abundance [25]. It is also affected by the external factors [26] such as the contributions of particles (clay, silt...) by the rising. In Kpassa reservoir, the measure of water transparency revealed a minimum value of $0.25 \mathrm{~m}$ (August 2014; St5) and a maximum of $1.92 \mathrm{~m}$ (January 2016; St1) (Figure 2). The values remain high in dry season (December 2014 to April 2015 and November 2015 to March 2016) to the fact that the floodgates of the reservoir are closed to maintain the volume of water. Accordingly, water stagnates and the suspended particles settle at the bottom making thus water transparent. As transparency is the inverse of turbidity, it is also almost influenced by the same factors. The high values of transparency obtained in dry season could be also related to the zooplancton because according to [27], the clear water phase is to be attached to the development of the zooplankton communities. Zooplankton contribute significantly to the clarification of water in the lakes and reservoir by the chattering of the phytoplankton [28]. In rainy season (August 2014 and September 2015), the low values obtained are because of the enrichment of the reservoir in particles brought by rain water from the basin. This could be also due to the organic matter produced by the aquatic plants and the development of the phytoplankton. The concentrations of chlorophyll a confirm this notice. Chlorophyll a values varies between $8.2 \mu \mathrm{g} / \mathrm{L}$ (January 2016; St1) and $233.46 \mu \mathrm{g} / \mathrm{L}$ (August 2014; St1) (Figure 3). The concentrations are high in rainy season (August 2014 and May 2016) reflecting the presence of an important phytoplankton biomass. The increase in chlorophyll a concentration during this period could be the consequence of the absorption of nutrients by the phytoplankton. In the dynamics of the phytoplankton, nitrogen and phosphorus plays a very significant role. The majority of the chlorophyll a values indicate a good water quality according to the standard $(<60 \mathrm{mg} / \mathrm{L}$ ) of [29] (Figure 3). The values of transparency reveal also a good water quality according to the standard established (2 m) by [29] (Figure 2).

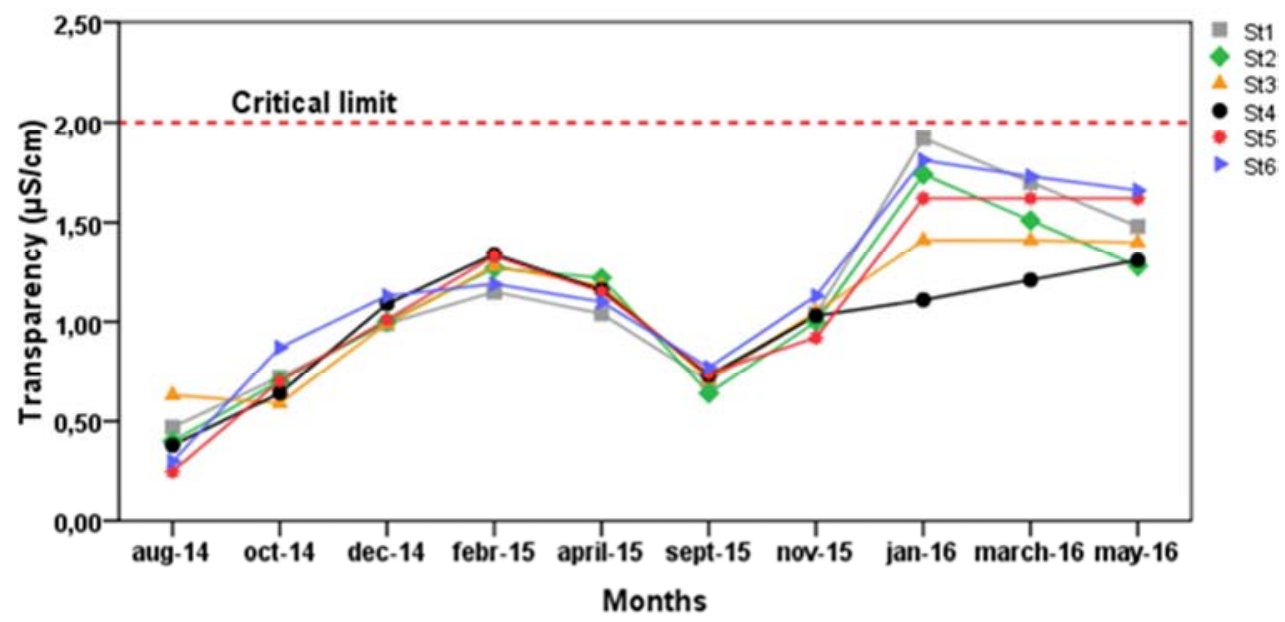

Figure 2. Variation of transparency at different sampling sites in Kpassa reservoir between 2014 and 2016.

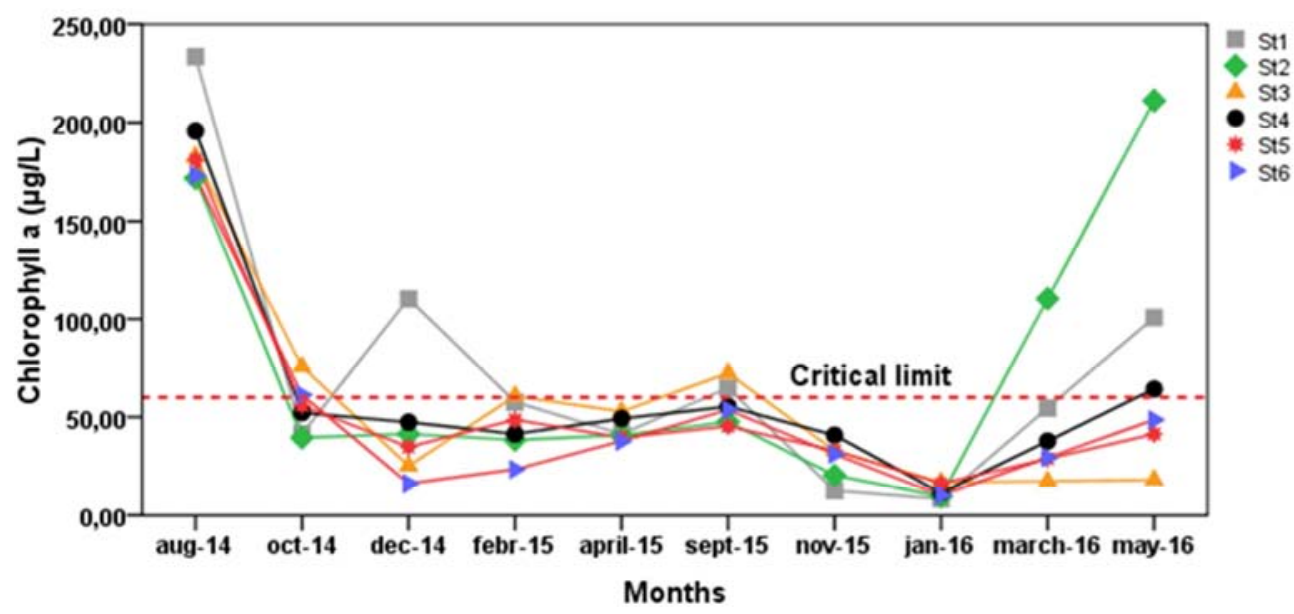

Figure 3. Variation of Chlorophyll a at different sampling sites in Kpassa reservoir between 2014 and 2016. 


\subsubsection{Nitrate, Nitrite and Ammonia Variation}

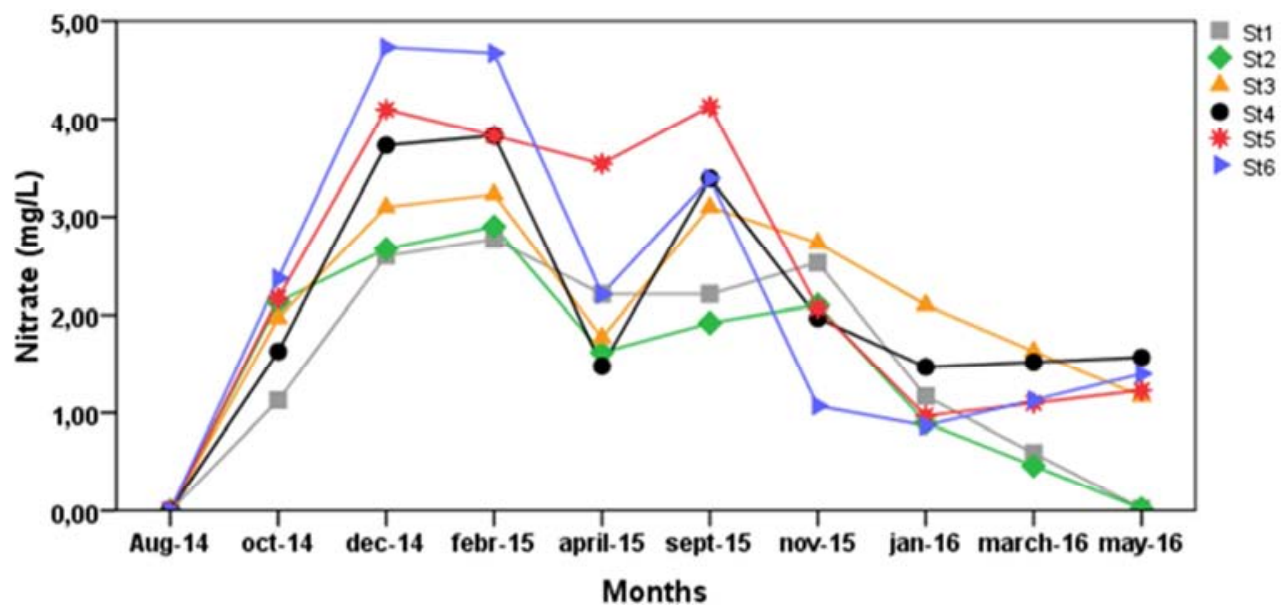

Figure 4. Variation of nitrate at different sampling sites in Kpassa reservoir between 2014 and 2016.

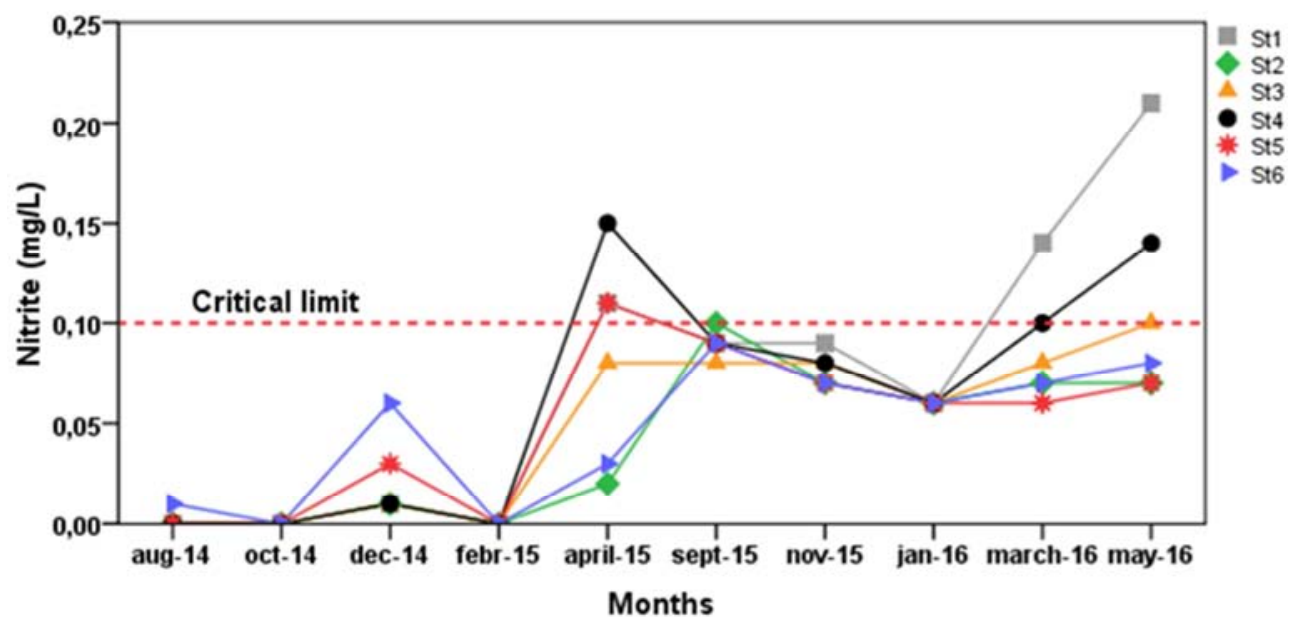

Figure 5. Variation of nitrite at different sampling sites in Kpassa reservoir between 2014 and 2016.

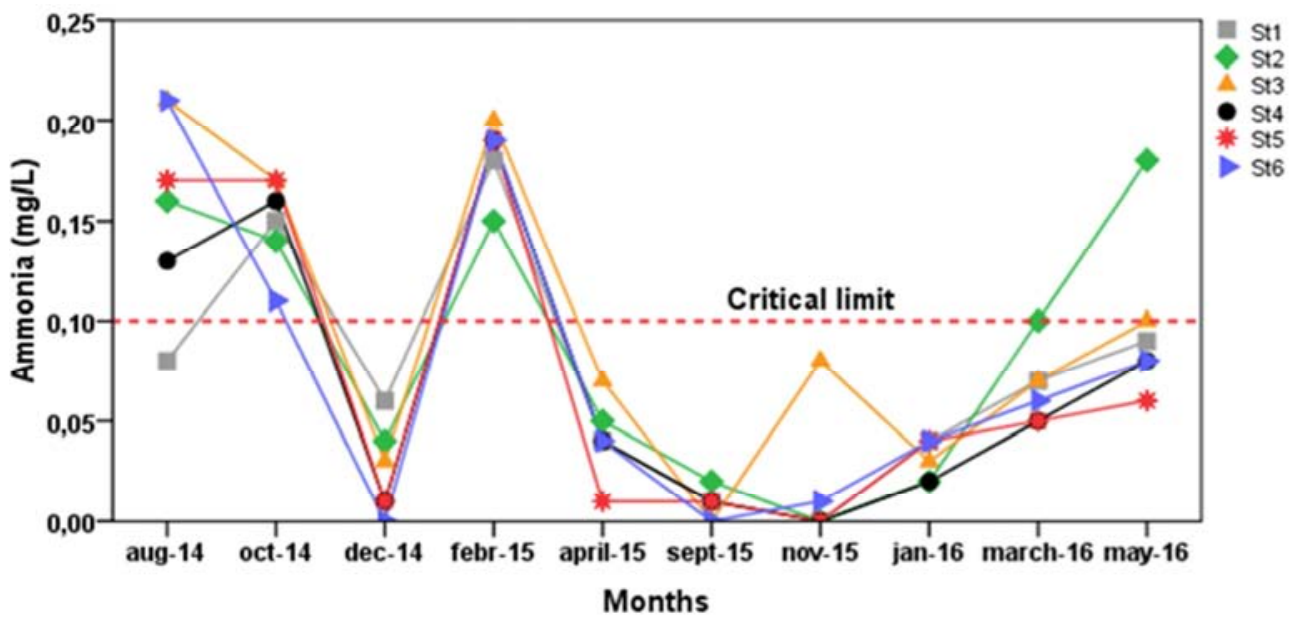

Figure 6. Variation of ammonia at different sampling sites in Kpassa reservoir between 2014 and 2016.

The most two problematic elements up to the functioning of aquatic ecosystems are nitrogen and phosphorus, since these two nutrients can take part in the eutrophication of surface water. The mineral nitrogen is present in water primarily in three forms: a reduced form (ammonia $\mathrm{NH}_{4}^{+}$) and two oxidized forms (nitrite $\mathrm{NO}_{2}^{-}$and nitrate $\mathrm{NO}_{3}^{-}$) [1] Human activities and mainly those related to agriculture are the major causes of the presence of nitrates and nitrites in surface water [30]. During the study, the maximum values of nitrate were obtained in dry season $(4.73$ and $4.67 \mathrm{mg} / \mathrm{L}$ 
respectively in December 2014 and February 2015 at St6) and in rainy season $(4.10 \mathrm{mg} / \mathrm{L}$ in September 2015 at St5) (Figure 4). High values of nitrite were recorded in April 2015 (dry season) and in May 2016 (rainy season) and are respectively $0.15 \mathrm{mg} / \mathrm{l}$ at station $\mathrm{St} 4$ and $0.23 \mathrm{mg} / \mathrm{L}$ at station St1 (Figure 5). The major peaks of ammonia were observed in rainy season during August $2014(0.21 \mathrm{mg} / \mathrm{L}$; St6) and October $2014(0.17 \mathrm{mg} / \mathrm{L}$; St5), and in dry season during February 2015 (0.19 mg/L; St3) (Figure 6). The high concentration recorded could be due to the agricultural and pastorals activities undertaken in the basin of Kpassa reservoir. Indeed the basin of the reservoir extends on houses area where frequent practices of intensive cultures and pastorals activities are undertaken. Massive quantities of artificial fertilizers and pesticides are periodically used. The cow dung produced by the farm of the Project of Development of Animal Production (PDPA) established in the East of the reservoir are added. All this joins together is washed in the reservoir in rainy period causing its enrichment in fertilizing elements. In dry season, there is no contribution but the reduction of the volume of the reservoir under the effect of evaporation contributes to increase its concentration in nutritive elements. Negligible concentration were noted for each one of these nutrients. Ammonia was not detected during November 2015, December 2014 (dry season) and
September 2015 (rainy season) (Figure 6). Nitrate remained undetectable during rainy season precisely in May 2016 and August 2014 except at stations St4, St5 and St6 (Figure 4). Nitrite appear negligible in August 2014 and October 2014 (rainy season) and in February 2015 (dry season) (Figure 5). The low concentrations obtained in wet period could be explained by the dilution effect generated by water coming from the basin and by the renewal of the reservoir water during the opening of the floodgate. In dry season, this is probably due to their consumption by algae and aquatic plants. However, nitrate values indicate a good water quality of the reservoir according to the standard $(<50 \mathrm{mg} / \mathrm{L})$ established by [31] (Figure 4). Nitrite pollution $(>0.1 \mathrm{mg} / \mathrm{L}$ ) was observed at sites St1, St4 and St5 in April 2015, March and May 2016 (Figure 5). It is the same for ammonia during October 2014, August 2014 and February 2015 (Figure 6). Nitrite is a toxic substance for human and organisms. Nitrites react directly with hemoglobin in human blood and other warmblooded animals to produce methemoglobin. Methemoglobin destroys the ability of red blood cell to transport oxygen. This condition is especially serious in babies under three months of age, a condition known as methemoglobinemia or blue baby syndrome [32]. Ammonia also can cause acute toxicity symptoms for many aquatic organisms [1].

\subsubsection{Orthophosphate and Total Phosphorus Variation}

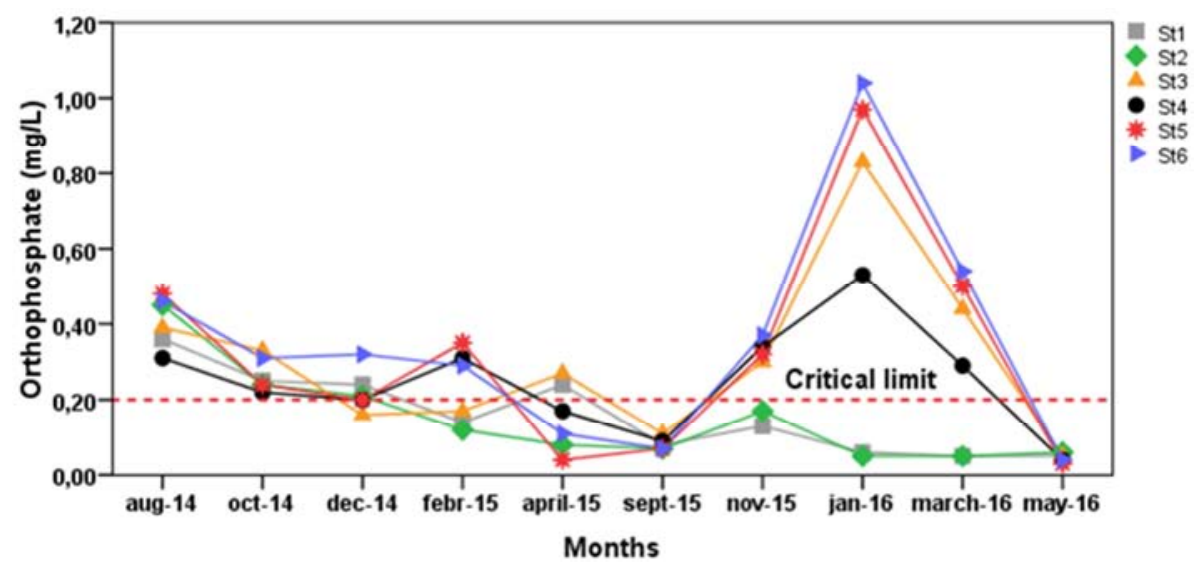

Figure 7. Variation of orthophosphate at different sampling sites in kpassa reservoir between 2014 and 2016.

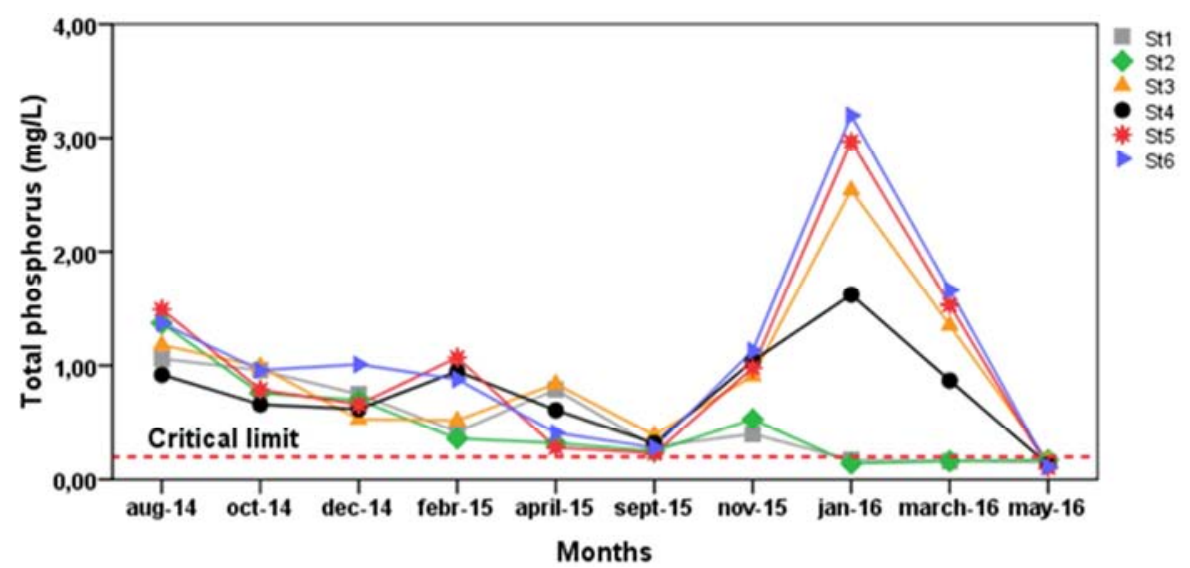

Figure 8. Variation of total phosphorus at different sampling sites in kpassa reservoir between 2014 and 2016. 
Phosphorus is a part of the most important nutrients of an ecosystem. In aquatic systems, phosphorus originates naturally from the dissolution of phosphate minerals and mineralization of algae. Anthropogenically, phosphorus originates from sewage discharges, industrial effluents, as well as diffuse inputs from grazing and agricultural land [33]. Mineral phosphorus is present in water primarily in the form of soluble or insoluble phosphates (orthophosphates and polyphosphates) [1]. In Kpassa reservoir, orthophosphate values range from $0.03 \mathrm{mg} / \mathrm{L}$ (May 2016; St5) to $1.04 \mathrm{mg} / \mathrm{L}$ (January 2016; St6) (Figure 7). The low values were obtained between August 2014 and September 2015 and the high values between January and March 2016. Total phosphorus dynamic is almost similar than orthophosphate's. Its values oscillate between 0.1 $\mathrm{mg} / \mathrm{L}$ (September 2015; St5) and $3.2 \mathrm{mg} / \mathrm{L}$ (January 2016; St6) (Figure 8). High values of orthophosphate and total phosphorus observed in Kpassa reservoir could be due to the fertilizers used in agricultural activities undertaken in the basin. The reservoir is also permanently fed with phosphorus of soaps. Indeed the populations of Kpassa reservoir basin are frequently devoted to washing and crockery activities along the river which supplies the reservoir in water. Low values recorded in rainy season could be thus due to the dilution effect generated by rainwater. Regarding the dry season, the reduction of the volume of water in the reservoir under the effect of evaporation could be at the basis of the increase of phosphorus concentration. According to [34], orthophosphate is the major source of phosphorus used by phytoplankton, sometimes at very weak concentrations. Orthophosphate assimilation by algae and aquatics plants could thus contribute to reduce its concentration in water. Low values of phosphorus recorded in dry season could be related to this notice. Compared with the standard $(<0.2 \mathrm{mg} / \mathrm{L})$ of [31], about $50 \%$ of orthophosphate values indicate a good water quality of the reservoir (Figure 7). As for total phosphorus, except in May
2016, its values indicate a poor water quality of the reservoir according to the standard $(0.2 \mathrm{mg} / \mathrm{L})$ of [31] (Figure 8 ).

\subsection{Trophic State Variation}

The application of the trophic state index (TSI) of [8] in Kpassa reservoir revealed values oscillating between 38 (January 2016; St2) and 59 (August 2014; St5) (Figure 9). The whole studied sites reached their maximum trophic state in rainy season (August 2014). Indeed, the trophic state index decrease from August 2014 to October 2014, stabilize almost from December 2014 to January 2016, then increase from March 2016 to May 2016. According to the thresholds established by [8], Kpassa reservoir is eutrophic in August 2014 at the whole studied stations. [11] found similar results on the basis of [35] classification. According to this author, the trophic state of the reservoir ranged from a mesotrophic state in 1975 towards a eutrophic state since 1995, after only twenty years of exploitation. The trophic state of the reservoir seems deteriorated years by years. This notice is confirmed by [36] who classified the reservoir as hypereutrophic by analyzing total phosphorus and chlorophyll a values. But in the present study, the majority of the trophic state index values are characteristic of mesotrophic conditions. Over the period going from October 2014 to May 2016, the reservoir was characterized by a mesotrophic state with a tendency to oligotrophy only in January 2016. The three stations of the reservoir concerned by oligotrophy are St1, St2 and St6. We could conclude that the trophic state of the reservoir improved but this result could be due to the depth of sampling. Indeed, the water samples were taken in depth, at $30 \mathrm{~cm}$ from the water surface. Sampling carried out more in depth could revealed similar results than those obtained by [11] and [36].

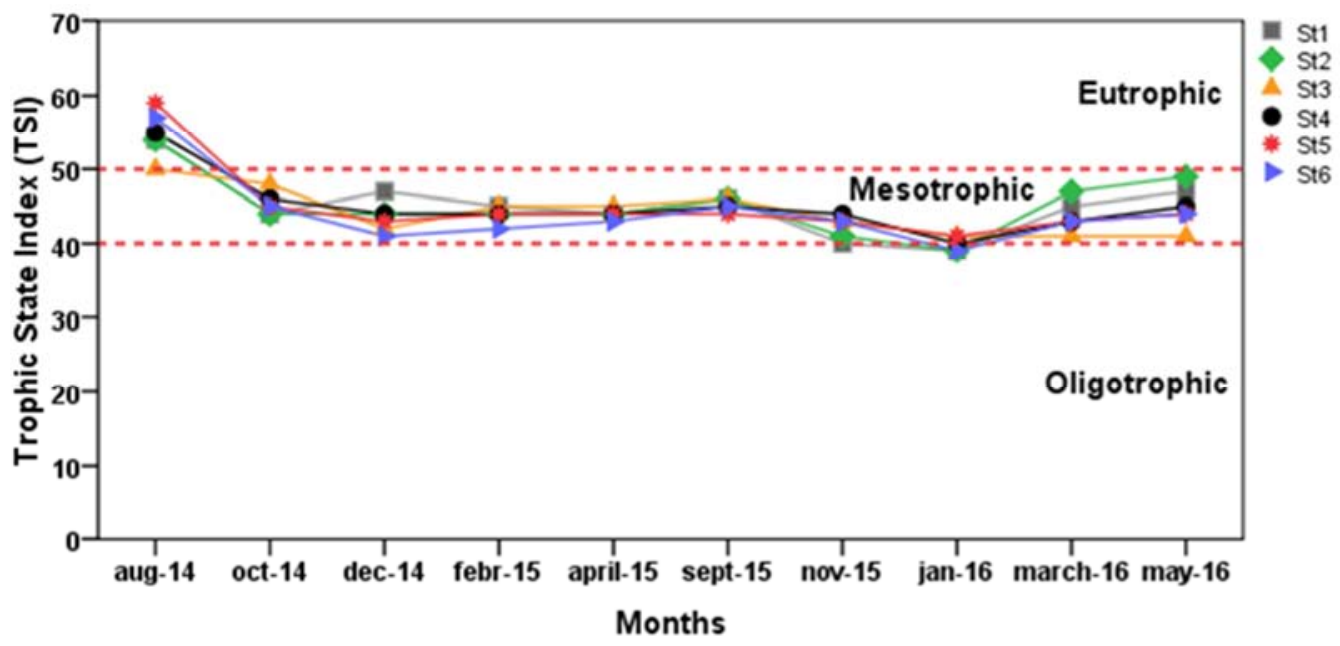

Figure 9. Variation of Trophic State Index (TSI) at different sampling sites in Kpassa reservoir between 2014 and 2016.

\subsection{N:P Ratio Variation}

Figure 10 presents the spatio-temporal dynamic of $\mathrm{N}: \mathrm{P}$ ratio in Kpassa reservoir. N:P ratio increase from August 2014 to
September 2015, decrease from November 2015 to March 2016 and increase again in May 2016. Its values vary between 0.22 (August 2014; St1) and 60.46 (September 2015; St5). 
These values are lower on the whole studied sites than Redfield ratio in dry season (December 2014, November 2015, January 2016 and March 2016) and in wet season (August 2014 and October 2014), suggesting a limitation of nitrogen. Phosphorus constitutes on the other hand the limiting element in September 2015 and May 2016 regarding the wet season and in February 2015 and April 2015 concerning the dry season. This tendency show that N:P ratio evolves independently of the seasons. The same notice was made by
[11] according to whom N:P ratio varies between 4 and 100 one year to another. For [36], N:P ratio fluctuates between 2.54 and 63.25 and nitrogen constituted the limiting factor most of the time. The primary production in Kpassa reservoir is thus controlled by a lack of nitrogen and phosphorus. However, phosphorus appear as the most frequent limiting factor in fresh waters and various eutrophic lakes of the tropical areas [37]. Other factors like light intensity, transparency or water temperature also control the increase of algal biomass [1].

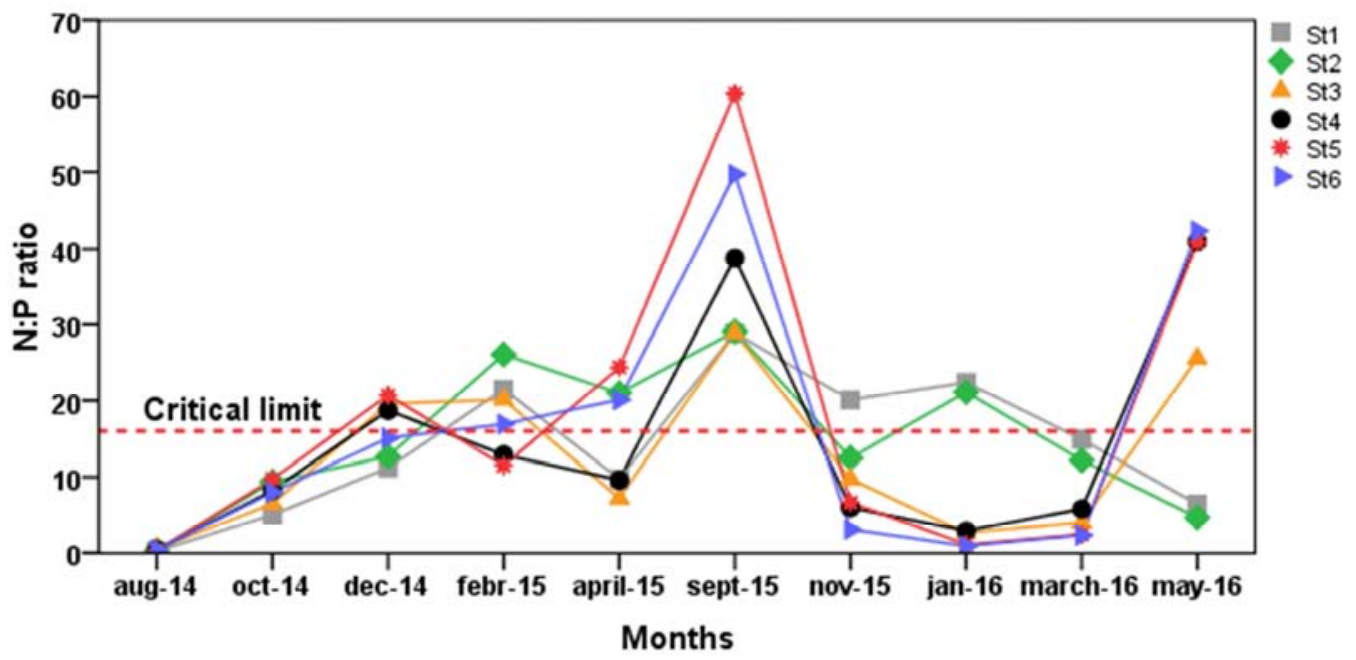

Figure 10. Variation of N:P ratio at different sampling sites in Kpassa reservoir between 2014 and 2016.

\section{Conclusion}

The physico-chemical parameters investigated presented some values outside of the WHO and Ifremer safe limit. This indicates that Kpassa reversoir water is unfit for human consumption at the concern sites and during the concern period. Fertilizers and pesticides used in agricultural and pastorals activities undertaken in the basin of the reservoir added to soaps used in washing and crockery activities along the reservoir river may be the principal cause of the high levels of the physico-chemical parameters. The cow dung produced by the farm of the Project of Development of Animal Production (PDPA) established in the East of the reservoir may also impact the reservoir water quality. Thus, it is recommended that the national company of Benin water (SONEB) sensitize the population on the rational use of the fertilizers and the adoption of water control technics in the farm. The agricultural lands runoff will be reduced and consequently the concentrations of nutrients in the reservoir. Also, washing and crockery activities should be forbidden along the reservoir river.

The majority of the trophic state index values are characteristic of mesotrophic conditions. Kpassa reservoir is eutrophic only in August 2014 at the whole studied stations. Compared to [9] and [30] results, the trophic state of the reservoir seems improved.

Eutrophication in Kpassa reservoir is limited by phosphorus and nitrogen. Measurements to be implemented for its management should emphasize on the control of the flow of nitrogen and phosphorus compounds.

\section{Acknowledgements}

The authors would like to acknowledge Dr Dieudonné Zogo, Director of "Société Nationale des Eaux du Bénin Parakou (SONEB Parakou)" for his special support. We are also grateful to M. Mohamed Bouré, M. Akilou Socohou and M. Gaël Sounouvo for field and lab assistance.

\section{References}

[1] Brahy V. L'eutrophisation et l'enrichissement en nutriments. Wallonie, 18p, 2007.

[2] Sherrard NJ, Nimmo M and Llewellyn CA. Combining HPLC pigment markers and ecological similarity indices to assess phytoplankton community structure: An environmental tool for eutrophication? Science of the total environment. 2006, 361: 97-110.

[3] Dz. U. 2005/239/2019. Ustawa Prawo Wodne z dnia 18 lipca 2001 r. [Water Law Act of 18th of July, 2001].

[4] Zalewski M. Ecohydrology-the scientific background to use ecosystem properties as management tools towards sustainability of water resources. Ecological Engineering. $2000,165,1-8$.

[5] Akindele E. O. and Olutona G. O. Water Physicochemistry and Zooplankton Fauna of Aiba Reservoir Headwater Streams, Iwo, Nigeria. Journal of Ecosystems, Volume 2014, Article ID 105405, pp. 11. Doi: 10.1155/2014/105405. 
[6] Gulecal Y. and Temel M. Water Quality and Phytoplankton Diversity in Büyükçekmece Watershed, Turkey. Journal of Water Resource and Protection, 2014, 6, 55-61. DOI: 10.4236/jwarp.2014.61009.

[7] Kehayias G and Doulka E. Trophic state evaluation of a large mediterra-nean lake utilizing abiotic and biotic elements. Journal of Environmental Protection. 2014, 5, 17-28. https://doi.org/10.4236/jep.2014.51003.

[8] Carlson RE. A trophic state index for lakes. Limnology and $\begin{array}{lllll}\text { Oceanography. } \quad 1977, & 22 & \text { (2): } \quad 361-369 .\end{array}$ https://doi.org/10.4319/1o.1977.22.2.0361.

[9] Rast W, Holland M, Ryding SO. Eutrophication management framework for policymaker. MAB Digest 1, UNESCO, Paris, 1989.

[10] Hellström T. An empirical study of nitrogen dynamics in lakes. Water Environ. Res. 1996, 68, 55-65.

[11] Zogo D. Etude de l'élimination du fer et du manganèse lors de la potabilisation de l'eau d'une retenue en cours d'eutrophisation: Cas de la retenue d'eau de l'Okpara à Parakou au Bénin. Thèse de doctorat, Université d'AbomeyCalavi, Bénin, 2010.

[12] Tometin ASL, Daouda M, Zogo ND, Boukari O, Bawa LM. Eutrophication, Sediment phosphorus fractionation and short term mobility study in the surface and under profile sediment of a water dam (Okpara dam, Benin, West Africa). J. Appl. Sci., Environ. and Manage, 2013, 17, 517-526. http://dx.doi.org/10.4314/jasem.v17i4.9.

[13] Boukari TO, Mama D, Abou Y, Bawa LM. Physico-chemical features of the Kpassa reservoir, northen Benin, with emphasis on its trophic state: A preliminary study. J. of Environ. Protect., 2016, 7, 2067-2080. https://doi.org/10.4236/jep.2016.713161.

[14] Assouma K. Availability of water for the drinking water supply of the urban cen-ter of Parakou by 2025. DESS dissertation, University of Abomey-Calavi, Benin, 2008.

[15] INSAE. Provisional results of the fourth census of the Population and the dwelling. Cotonou, Benin, 2013.

[16] Suanon F, Dimon B, Mama D and Tometin AL. Study of the Sediments of the Dam of Okpara (Benin): Physico-Chemical Characterization and Speciation of Iron and Manganese. Journal of Water Resource and Protection. 2013, 5, 709-714. https://doi.org/10.4236/jwarp.2013.57071.

[17] Brabant Water and SONEB. AEP Parakou, development phase, studies report, fi-nal report. Parakou, Benin, 2014.

[18] PNE. Note of plea for the rehabilitation and the installation of a concerted mana-gement of Okpara dam, single source of AEP of the town of Parakou. Parakou, Benin, 2008.

[19] Le Barbe L. Surface water resources of Republic of Benin; ORSTOM Collection, Paris, France, 1993.

[20] Société Béninoise d'Energie et d'Eau (SBEE). Report of the hydraulic and hydrological study of Parakou zone; Ministry of Energy and Water, Cotonou, Benin, 1990.

[21] HACH. DR LANGE 2800 analysis handbook. HACH Company World Headquarter, Edition 1, Germany, 2005.
[22] Lorenzen G. Determination of chlorophyll and phaeopigments: spectro-pho-tometric equations. Limnol. Oceanogr. $\quad 1967, \quad 12, \quad 343-346$ https://doi.org/10.4319/10.1967.12.2.0343.

[23] Redfield JL, Ketchum BH and Richards FA. The influence of organisms on the composition of seawater. 1963 In: Hil, M. N. (ed). The sea, Willey, New York, 26-77.

[24] Dimowo B. O. Assessment of Some Physico-chemical Parameters of River Ogun (Abeokuta, Ogun State, Southwestern Nigeria) in Comparison With National and International Standards, International Journal of Aquaculture, 2013, Vol. 3, No. 15 79-84 (doi: 10.5376/ija.2013. 03.0015).

[25] Balvay G. Structure et fonctionnement du réseau trophique dans les retenues artificielles. Gestion piscicole des lacs et retenues artificielles. INRA, Paris, 39-66, 1985.

[26] Thomas S. Les différents producteurs primaires d'un petit barrage tropical africain: dynamiques et interactions (Brobo, Côte d'Ivoire). Thèse de Doctorat d'Etat, Université Paris 6, 246p, 2000.

[27] Jabari E. Structure et dynamique des populations zooplanktons de la retenue de barrage Allal El Fassi. Th. 3e cycle Université SMBA, 197p, 1998.

[28] Tuzin D and Mason. La clarification des eaux dans les lacs reservoirs. 56p, 1996.

[29] Ifremer. Mise à jour d'indicateurs du niveau d'eutrophisation des milieux lagunaires méditerranéens, Rapport final-09-2000, Tome I, 236p, 2000.

[30] Hamaidi-Chergui, F., Errahmani, M. B., Benouaklil, F. and Hamaidi, M. S. Preliminary Study on Physico-Chemical Parameters and Phytoplankton of Chiffa River (Blida, Algeria). Journal of Ecosystems, 2013, Article ID: 148793. https://doi.org/10.1155/2013/148793.

[31] WHO. Guideline for Drinking Water Quality, Vol 2, Geneva, 2008.

[32] Kumar M, Puri A. A review of permissible limits of drinking water. India J. Occup Environ Med. 2012; 16 (1): 40-44. DOI: 10.4103/0019-5278.99696.

[33] Mihale M. J. Nitrogen and Phosphorus Dynamics in the Waters of the Great Ruaha River, Tanzania. Journal of Water Resources and Ocean Science. Vol. 4, No. 5, 2015, pp. 59-71. Doi: $10.11648 /$ j.wros.20150405.11.

[34] Pourriot R, Meybeck M. Limnologie générale. Masson, Paris. Collection Ecologie. 6-59, 1995.

[35] OCDE. Eutrophication of waters. Monitoring, assessment and control, Paris, 1982.

[36] Tometin AL. Contribution à l'identification des sources et étude de remobilisation des métaux fer et manganèse dans un contexte d'eutrophisation au sein de la retenue d'eau de l'Okpara (Bénin). Thèse de doctorat, Université d'AbomeyCalavi, Bénin, 2015.

[37] Sommer U. Nutrient status and nutrient competition of phytoplankton in a shallow, hypertrophic lake. Limnol. Oceangr. 1989, 34, 1162-1173. 